\title{
SOMALI IMMIGRANT WOMEN IN THE CANADIAN LABOUR MARKET: BARRIERS AND CONSEQUENCES
}

By

Hani Leila Mohamed, HBA, University of Toronto, 2001

\author{
A Major Research Paper \\ presented to Ryerson University \\ In partial fulfillment of the requirements for the degree of \\ Master of Arts \\ In the Program of \\ Immigration and Settlement Studies
}

Toronto, Ontario, Canada, 2019

CHani Leila Mohamed, 2019 


\section{Author's Declaration Page}

I hereby declare that I am the sole author of this MRP. This is a true copy of the MRP, including any required final revisions.

I authorize Ryerson University to lend this MRP to other institutions or individuals for the purpose of scholarly research.

I further authorize Ryerson University to reproduce this MRP by photocopying or by other means, in total or in part, at the request of other institutions or individuals for the purpose of scholarly research.

I understand that my MRP may be made electronically available to the public. 
SOMALI IMMIGRANT WOMEN IN THE CANADIAN LABOUR MARKET: BARRIERS AND CONSEQUENCES

\author{
Hani Leila Mohamed \\ Master of Arts 2019 \\ Immigration and Settlement Studies \\ Ryerson University
}

\begin{abstract}
Somali women are experiencing barriers within the Canadian labour market due to islamophobia, racism, and their gendered roles. Like other racialized immigrants, Somali women's position within the labour market is peripheral. In Canada, racialized women experience precarious work, underemployment, unemployment and a noticeable wage gap. To add to these obstacles Somali women face the responsibility for social reproduction and lack in social capital. Somali immigrants and refugees in Canada have not received enough support from the government with regards to integration. Additionally, the labour market challenges and marginalization they experience results in poverty and has serious health consequences. However, Somali women exhibit resiliency and possess survival mechanisms. Inclusivity within the labour market for Somali women requires multi-sector policies and programs that combat inequality based on race, religion and gender.
\end{abstract}

Key Words:

Somali women, labour market, racism, islamophobia, social reproduction, social capital, Integration 


\section{Acknowledgements}

First, I would like to thank my MRP supervisor Dr. Sedef Arat-Koc for her guidance, support and encouragement, especially in making this project a very rewarding experience. I would like to also thank Dr. Grace-Edward Galabuzi who was my second reader for this paper and for being the catalyst in undertaking this topic as my MRP.

A would also like to thank my family in Canada and globally for being so supportive in my pursuits for higher education. They consist of my mom Amina, my sister Rahma, my cousin Asha, my niece Munira, and my brother in law Egal.

I would also like to thank all the professors in the ISS program for all the knowledge they imparted on us as students. I am very grateful.

Additionally, the memories I shared with my fellow classmates of the 2018-2019 cohort, will be forever cherished. 


\section{Table of Contents}

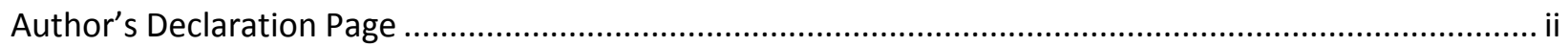

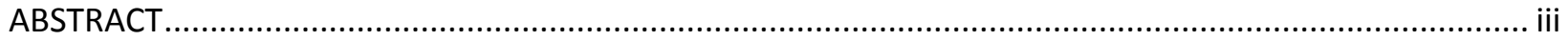

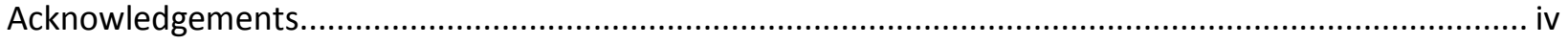

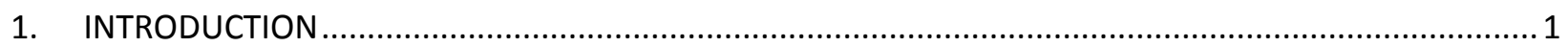

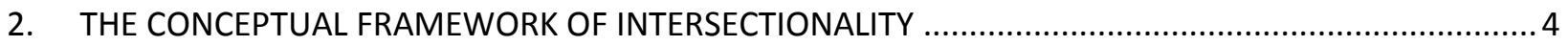

3. ANALYSIS OF THE LABOUR MARKET BARRIERS FACED BY SOMALI WOMEN ..................................

3.1 The Place of Racialized Women in The Canadian Labour Market …............................................ 9

3.2 Portrayal of Muslims in Canada and Globally; Implications for the Labour Market ........................14

3.3 Common Assumptions and Biases About Somali Women ........................................................18

3.4 Social Networks, Social Capital and the Labour Market .........................................................20

3.5 Gender, Social Reproduction and Relationship to the Labour Market......................................22

3.6 Settlement Policies and Practices of the Canadian Government ................................................24

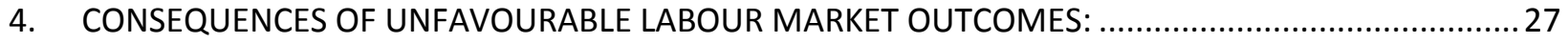

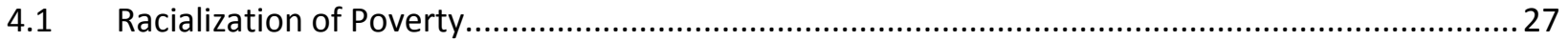

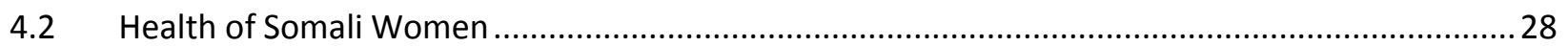

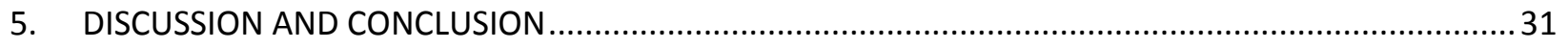

5.1 Survival and Resilience in an Unwelcoming and Unequal Environment .....................................33

5.2 Towards an Inclusive Labour Market for Racialized and Gendered Immigrants ..........................36

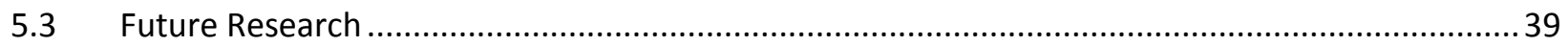

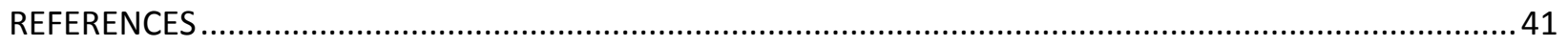




\section{INTRODUCTION}

In Canada, Somali women are a vulnerable population especially when it comes to the labour market on the basis of race, religion and gender. The literature demonstrates that there are many barriers that women of colour face in the labour market, and Somali women are no exception. Some of the barriers they face are racism, islamophobia and gender discrimination just to name a few. The key research question that guides this paper is: What are the barriers that affect women of Somali descent in the labour market in Canada, especially in accessing professional well-paying jobs? This paper aims to study the literature and examine the possible obstacles that exist when it comes to Somali women and their entrance into the labour market in Canada. As racialized women this review investigates their place within the Canadian labour market; their portrayal as Muslims both locally in Canada and Globally; biases and assumptions that comes with their identity as immigrants and refugees; the importance of social capital; the social reproduction barrier that blocks their place in gaining optimum labour market success and finally the role of the Canadian government when it comes to integration and settlement. Moreover, one has to examine how Somali immigrant women have reacted to this unequal environment. Lastly, possible solutions that are mostly government led multi-sector policies that combat inequality in the labour market are introduced.

Somalis came to Canada fleeing the civil war that raged in what is known as the Horn of Africa and where the country of Somalia is situated. This civil war raged between 1978 and early 1990s. It was a conflict perpetrated by a dictator named Siad Barre who ruled for 21 years and was finally defeated after clashing with rebel groups that had different clan affiliations. This war took 500,000 thousand lives, resulting in Somalis seeking refugee protection in a number of countries including Canada, Australia, England, Netherlands, Sweden and Norway (McMichael and 
Manderson, 2004, p.88). Around 37,875 Somalis arrived In Canada in the late 1980s early 1990s to an unwelcome atmosphere that involved misunderstanding and stereotypes (Bokore, 2013, p.96). Upon arrival, a majority of Somalian refugees settled in major cities such as Toronto (Bokore, 2013).

Somalis were portrayed as "poverty-stricken, violent and backward people" (Spitzer, 2006, p.49). At the time of arrival, the typical narrative surrounding Somali immigrants was that they would 'drain national resources'. There were "stories of Somali warlords entering the country and Somali women committing welfare fraud were woven into the primitivist images of Somali society" (Spitzer, 2006, p.49). These narratives which continue to plague Somalis to this day do not take into account the main issues of displacement and postmigration that Somali women and the Somali community have had to deal with (Bokore, 2013). These issues include discrimination in schools, the labour market (which this paper delves into in greater detail); and ghettoized housing conditions that have put the youth in dangerous spaces where they have become susceptible to crime/violence statistics (Bokore, 2018). Therefore, upon arrival, Somalis had to deal with being part of a racialized and marginalized community, facing a different form of exclusion and marginalization from the one they experienced in the clan-based society they had come from. The marginalization that was in existence now was one based on race, religion and not on clan.

Addressing the issues of Somali-Canadian women is very important as they have now become the head of households in the diaspora. These women do not come from matriarchal societies, rather they come from patrilineal ones and the fact that female-headed households are now the norm is a direct by-product of the civil war (Mohamed, 2007). Reasons behind this phenomenon are three-fold: first, Somali Canadian women became widows after the civil war. 
Second, the migration process separated women from their husbands as it was women and children who were sent abroad ahead. And third, due to the unemployment issues that the men were facing in Canada, they had to leave their wives to find work in other regions (Mohamed, 2007). Canadian statistical evidence reveals that $70 \%$ of the community are living below the poverty line. This is in comparison to all ethnic groups in the province of Ontario (National Council of Welfare, 2012, p.2). A Statistics Canada study in 2006 also looked at Ethiopian, Jamaican and Filipino immigrants (just to name of a few), all of whom ranked better than the Somali community.

The paper used close to 56 peer reviewed articles on experiences of racialized immigrant women, Somali immigrant women and Muslim women in the Canadian labour market and the diaspora. The paper also drew on literature from the Somali community in the diaspora of Sweden, the United Kingdom and Australia as most of the research on Somali refugee women were done in those countries 


\section{THE CONCEPTUAL FRAMEWORK OF INTERSECTIONALITY}

Somali immigrant women have unique multiple identities due to their religion, race and gender. Hence, one of the most relevant conceptual frameworks is Intersectionality. Intersectionality is defined "as a way various socially created categories interact in interconnecting or overlapping systems of oppression" (Tariq and Seyed, 2018, p.496). Browne and Misra (2003), who cite Collins (1999), state that intersectionality is about "the 'interlocking systems of race, class and gender' as constituting a 'matrix of domination.' Within this matrix, an individual can simultaneously experience disadvantage and privilege through the combined statuses of gender, race, and class" (p.489). Hence, most scholars have used the conceptual framework of intersectionality to measure inequality especially with groups that have intersecting identities. Black women in particular have had to deal with the social constructions of race and gender and the biased labels that come with these identities. Collins (1999) refers to some of these false images of black women as being 'jezebels,' mammies' and 'welfare queens' (Browne and Misra, 2003, p.490). These perceived stereotypical identities are dangerous and can make their way to the ways in which Black women are viewed; especially in such institutions as the labour market.

Somali women are part of the vast majority of Muslim women in Canada and globally who are also identified as visible minorities (Khattab et al. 2018). Hence, their participation in the labour market is marred by how individuals or the system views them and treats their divergent characteristics (Khattab et al. 2018). Khattab and Hussein (2018) point out:

Muslim women do not enter the labour market solely as women; they face a multitude of challenges invoked by their ethnicity, race, migration status, culture and religion. They also cannot be treated as a homogeneous group as issues of race, ethnicity, migration and class are of great importance in understanding their multiple identities as well as experience... In this context, Muslim women occupy multiple positions and identities that are complex and multi-directional. The visible identity for some, especially when wearing the veil or hijab, as well as 
other markers such as colour and dress code, play an important part in the construction of 'otherness'... and reflect the intersectionality and shifting nature of race and ethnic boundaries. (Khattab and Hussein p.10)

It is important to mention that the intersectional paradigm requires "understanding one category of oppression necessitates understanding of how it intersects with other categories of oppression" (Premji and Shakya, 2017, p.28-29). Hence, this is why race and religion and gender identities that affect Somali women are analyzed in this paper, especially in relation to the labour market, and are not singularly exclusive. However, for Somali women one has to add religion as a factor in the social exclusion they face (Browne and Misra, 2003). This is especially important in the period since $9 / 11$.

Scholars that study intersectionality also look at the power relations evident when one is analyzing this concept (Collins, 2015). What makes the conceptual framework of intersectionality applicable is that it examines the power relations that are associated with the marginal social status of being Black, Muslim and a woman. In addition, this conceptual framework unlike other frameworks that concentrate on either the identity of gender or the identity of race, mentions the intersections of race, religion and gender (Browne and Misra, 2003). In discussing the issue of intersectionality in the labour market, Browne and Misra (2003) talk about the unequal divisions and social stratification. In using the example of Latinas in the labour market; these authors talk about the privilege that comes with being a white woman and being viewed as "professional workers" while women of colour like Latina women are racialized and gendered relegating them to precarious work of taking care of the households of white families through childminding and elder care (Browne and Misra, 2003).It is important to mention that within the socially constructed hierarchy white men are "individuals who occupy the highest levels of multiple social categories-White men-will accrue the greatest privilege, 
power, and prestige" (Browne and Misra, 2003, p.493). Therefore, the intersections and the social construction identity of being white and male at the same time has brought about them occupying the highest levels within the labour market. Nevertheless, "Intersectionality requires that we recognize the differences in experience between black women and white women" (Canham and Maier, 2018, p.322). In their analysis of intersectionality, Canham and Maier (2018) show how increasingly white women often occupy high ranking managerial status in professional fields such as banking. They demonstrate this by studying the difference between Black and White women within the context of South Africa. In examining the three identities of class, race and gender in the labour market, Canham and Maier (2018), state, "race and class privilege is the default drive that gives white women access to power in a manner that gender is unable to" (p.336). Thus, proving that intersections of different identities that white women possess racially as well as due to their gender can either work for or against them.

Moreover, the struggle to attain well-paying professional jobs is a struggle that all racialized women share. In the case of Somali women, the socially constructed identities associated with being Muslim, Immigrant, Black and female bring forth specific stereotypes, as well their perception as being unskilled (as refugee/immigrant), which has kept them at the bottom within the labour market (Spitzer 2006, Bokore, 2017). Somali female scholar Nimo Bokore (2013), who has written extensively on the plight of Somali women in Canada articulates her experience as a single mother whereby despite having a post-secondary education and a career as a journalist, she still had to spend five years having to repeat her education in order to update her credentials and skill set just to be able to earn a living to feed her family (Bokore, 2013). Here, you have the intersection of her identity as a refugee (being deemed unskilled) as 
well as her gendered identity (having to take care of her children solely) having a tremendous impact on her life.

While they share some of the obstacles and challenges that other groups of immigrant women (especially Black, and Muslim immigrant women) experience, Somali women's identities and experiences are also unique and specific. Somali immigrant women have a strong connection to their religious and ethnic identity and they generally tend to refuse to assimilate to western ideals. Although they often do not assimilate (especially first-generation women) they have adapted to the Canadian socio-economic environment however difficult the adjustment period has been. The second generation, often known as generation 1.5 (born in Somalia but grew up in Canada), have come to struggle with hybrid identities. They blend in neither with the societies back home nor with Canada (especially due to racism and Islamophobia they face when it comes to the labour market). Another aspect of a Somali women's identity has to do with the importance they place on kinship. Even within the context of Canada, every Somali woman knows their family tree and is identifiable ancestrally. Therefore, though these women share some similarities to other racialized immigrants in their identities and experiences, theirs are also distinct due to the above-mentioned characteristics. Their experience as refugees fleeing a war tone country and having to deal with language barriers is yet another identity marker that can be added. According to Mohamed (1999), Somali women in Canada lead "fragmented lives and identities in a new cultural, linguistic, and structural environment" (p.56). Therefore, Intersectionality as a concept is relevant in helping to understand the complex everyday reality of a Somali immigrant woman in Canada and the ways in which she negotiates her multiple identities. 


\section{ANALYSIS OF THE LABOUR MARKET BARRIERS FACED BY SOMALI WOMEN}

Somali immigrant women face racialization in the labour market, like other women of colour; therefore, this analysis situates racialized women's place within the labour market. Also, as Muslim women the way they are viewed globally as well as in Canada makes a big difference. Third, the ways in which their status as immigrants and refugees are portrayed can potentially influence institutions such as the labour market. Fourth, the lack of social networks leading to weak social capital is analyzed. The absence of assistance with social reproduction is examined. The lack of Canadian government's assistance with settlement and integration is studied.

There is a very small literature of studies directly focusing on Somali immigrant and refugee women in Canada. One of my main sources for this paper has been Nimo Bokore (2018), a Somali Canadian author who has written on issues facing Somali immigrant women and their migration process to Canada i.e. islamophobia, racism and labour market obstacles (lack of credential recognition at arrival); causing re-traumatization (due to civil war and difficult reintegration into Canadian society). Another important source is by non-Somali Canadian author Spitzer (2006), who touches on how immigration has had an impact on Somali women in Canada in entering the labour market. This author's article is important as it sheds light into the earlier years in the 1980's when Somali women arrived in Canada as refugees and what happened to them with regards to the labour market (also the lack of credential recognition) and why they continue to lag behind socio-economically. Spitzer (2006) speaks to consequences of bureaucratic discrimination that made these women wait for papers leading to health effects.

The literature lacked in assessing the difficulties Somali women face when trying to enter the Canadian labour market and whether such obstacles play a part in them acquiring professional jobs i.e. managerial jobs, jobs that often have benefits and are not precarious in 
nature. Still, one can draw on research by Khattab et al (2018), who drew on statistical information on how Muslim women are affected by labour market outcomes due to their religion in Canada. The above-mentioned authors used the National Household Survey (NHS) of 2011 which provided a sample of 192,652 working age Canadian women of 18-24; and also, another study done by Khattab and Hussein (2018) which used a sample of 245,391 Muslim women. In addition, many scholars relied on the 2006 Census to draw out the experiences of racialized women and communities in the labour market and which this paper relies on for statistical data. Also, research by Dr. Grace Edward Galabuzi $(2004,2006,2011)$ provides clear research of the situation of racialized women and communities in the Canadian labour market in comparison to non-racialized men and women (in particular key statistical information). Literature of racialized Canadian women researched by Das Gupta et al. (2014) and Premji et al. (2014) who provide key findings of the troubling trend of precarity and deskilling occurring in the Canadian labour market fills the gap in scholarly work.

\subsection{The Place of Racialized Women in The Canadian Labour Market}

Racialized people in Canada continue to experience unfavourable positions within the labour market and Somali women are sure to be part of this vulnerable population. The 2006 Census data shows that "despite years of unprecedented economic growth and an increasingly diverse population...many Canadians have experienced in real life: a colour code... that blocks them from the best paying jobs that our country has to offer" (Galabuzi and Block 2011, p.3) This colour code (which is essentially racial inequality) within the Canadian labour market reported by Galabuzi and Block (2011) results in a significant income gap between racialized and nonracialized Canadians and creates a precarious status for the former in the labour market. Das Gupta et al. (2014) have found that many racialized immigrants attained post-secondary 
education in their country of origin, and yet have had to re-educate themselves. In citing Man (2004) and Shan (2009), they state " the majority of professional immigrants experience downward mobility in the labor force," whereby "discourses and practices downgrade their credentials and abilities" (p.67). In assessing the Chinese and Indian women immigrant's access to professional jobs in Canada, Das Gupta et al. (2014) point out that "they are thus forced to take up entry level jobs that are poorly remunerated compared to their white Canadian counterparts with similar or identical qualifications and work experience" (p.67). Lightman and Gingrich (2018), talk about this also, and refer to this phenomenon as economic exclusion in the Canadian Labour market structure which affect women and members of racialized communities: ...Canada's labor market functions to generate and reinforce uneven social groups, as well as clear and sustained divisions between them...perceived ethno-racial identity matters...individuals identified as Black, South Asian and Arab, as well as recent immigrants and women, are the most over-represented in the most excluded quintile of our Economic Exclusion Index in 2000 and 2010. (p.414)

Galabuzi and Block (2011), revealed that when it comes to unemployment "the gap is worse for racialized women, whose unemployment rate was $1.5 \%$ points higher than racialized men and 3 percentage points higher than non-racialized men" (p.7). In addition, racialized women are $48 \%$ more likely to be unemployed than non-racialized men (Ibid, p.4). This may contribute to the fact that racialized women earn 55.6\% of the income of non-racialized men. (Galabuzi and Block, 2011, p.4).

The Somali community is at the bottom of the Canadian socio-economic ladder and Somali women fall under this category as well (The National council of Welfare Report, 2012). Somali women's experiences in the labour market can be closely linked to those of the fellow educated immigrant women from Sub-Saharan Africa who "face particular difficulties finding 'survival jobs' because of demands for Canadian experience, credentials and accents..." (Premji et 
al. 2014, p.123) These survival jobs refer to both high skill and low skill jobs just to earn a living in Canada. This situation that the Somali Community as well as Somali women find themselves in are due to the lack of access to well-paying jobs. Somali women are not the only ones going through this: it is estimated when it comes to the pay gap "racialized Canadians earn 81.4 cents for every dollar paid to non-racialized Canadians" (Galabuzi and Block, 2011, p.11).

The restructuring of the Canadian economy due to globalization and neo-liberalism has also played a part in shaping and perpetuating inequalities in the labour market. Galabuzi (2006) states that it is often the vulnerable who suffer; and they consist of racialized groups, women, immigrants and refugees. This new economy not only brought forth precarious, temporary, contract, casual jobs with low wages, no benefits, lack of job security and substandard working conditions; but it also intensified the racial and gender divide in the Canadian labour market based on institutional discrimination (Galabuzi, 2006). Even though the rates of participation for the racialized members of the Canadian community are higher than non-racialized Canadians within the labour market, they are found in such low paying jobs as call centre, security and janitorial posts (Galabuzi and Block, 2011, Lightman and Gingrich 2018).

The Canadian labour market is a highly racialized space, especially for women of colour. A study by Premji et al. (2014) of racialized immigrant women in Toronto uncovered that women who were health care professionals in their home country found themselves working as personal support workers and day care assistants, in a process that is referred to as deskilling. In addition, in the same study by the latter authors demonstrated that "participants employment pathways showed very high levels of employment precarity marked by multiple short periods of employment and lengthy periods of unemployment between jobs" (Ibid, p.128). Das Gupta et al. (2014) in their survey of Chinese and Indian Internationally trained immigrant women, found 
that 7 out of the 23 had to take on call centre positions which they described as "demeaning," "repetitive" and with "irregular" working conditions (Das Gupta et al., 2014, p.71). In addition, out of the 23 women interviewed only two were able to "re-enter their former fields" (Ibid, p.67). As part of the racialized community Somali women are bound to be caught up in this unfortunate trend. Premji et al. (2014) point out that it is racialized immigrant women that are "overrepresented in low-paid, low- skill jobs characterized by high risk and precarity" (p.123). According to Galabuzi (2006) "a growing body of Canadian studies suggests that flexible work arrangements, facilitated by state mediated processes of deregulation of the labour market, have particularly disadvantaged racialized groups, and especially racialized women" (Galabuzi, 2006, p.10).

Also, when racialized women gain education, whether they belong to the first-generation or second-generation; their salary is still lower than their non-racialized cohorts (Galabuzi \& Block, 2011, p.11). In the case of Canada, Galabuzi and Block (2011) found that second generation racialized women with a university degree were earning $\$ 42,804$, in salary as compared to non-racialized women at $\$ 46,391$. First-generation racialized women earned $\$ 32,165$ compared to first-generation non-racialized women at $\$ 39,624$. The differentials in percentages is $92.3 \%$ for second-generation racialized women compared to their non-racialized counterparts; and the differentials for the first-generation racialized women is $81.9 \%$ in comparison to non-racialized women (Galabuzi and Block,2011, p.11). Second generation Somali women no longer face the credential recognition obstacles that their mothers of the firstgeneration went through, however they are still earning less than non-racialized Canadians and are more likely to be in precarious situations within the labour market (Galabuzi and Block, 
2011). This is despite the fact that they possess the same skills and education as their nonracialized counterparts.

This high racial inequality in the labour market meant that first-generation Somali women would retreat from this scenario by creating micro-enterprises. Spitzer (2007) demonstrates further the entrepreneurial activities that these women engage in, she affirms that they "...share wares such as Arabic perfumes and Somali dresses imported by travelling family members or foodstuffs cooked at home and sold to households in their apartment block" (p. 57-58). The issue of credentialing affected the first-generation in particular after arrival in Canada. Jesow (2016) studied 50 Somali women in the Somali flea market of Suuqa Ceelgaab in Toronto, states that:

Numerous women illustrated that they were often turned down by potential employers and/or deemed unqualified, in spite of their training and experience. For instance, a qualified nurse expressed her frustration after being told her heavy accent would limit patient-nurse communication. (p.86)

This retreat from the formal labour market is corroborated by a recent study by Picot et al. (2019) of statistics Canada, who reported that after five years of settling in Canada as refugees, only 1 in 5 Somali women were working (para. 4). Jesow (2016) goes on to say, "feelings of exclusion and perceptions of being unwelcome in the host country significantly discourage immigrant women from seeking employment in the Canadian labour market" (p.86). Thus, this was the predicament that Somali women found themselves in. Hence, they were faced with the following choices: re-educating themselves; entering the precarious labour market; or start a small business. A study done by Premji and Shakya (2017) which included Somali women found that they were engaged in precarious work that did not match their education or skills. This is corroborated by members of the Somali community who found that Somali women were found in low-skill jobs which were difficult in nature like: personal support workers (PSWs), home 
child care providers, lunch room supervisors and school bus drivers, just to name a few (jobs that for the most part offer no benefits or pensions).

\subsection{Portrayal of Muslims in Canada and Globally; Implications for the Labour Market}

There is substantial literature that addresses Islamophobic portrayals of Muslim women (in general) in the media, internationally and in Canadian society (Bullock, 2000, Said, 1979). It is important to mention here that "Islamophobia is rooted in racism and is a type of racism that targets expressions of Muslimness or perceived Muslimness” (Streeting, 2019, para.4). Bullock (2000) States:

There are dominant and recurrent themes of Muslim women that prevail... harem bellydancer character, the mysterious and sexualized woman of the 'Orient'; the second is 'the oppressed Muslim woman,' often represented as the hijab wearer or the woman who is unable to drive; and, finally, there is the "militant Muslim woman," often shown in hijab with a gun and military clothes. These personas are in line with the general Western "cultural consensus"... of Islam as a static, backward, exotic and barbaric religion--a discourse on Islam better known as 'Orientalism' (p.2-3).

A significant gap within this literature has to do with the ways in which these types of depictions then manifest themselves in Canadian institutions such as the labour market. These stereotypes alone could be enough to deny a person a position that they so rightly deserve in the labour market based on false assumptions made about one's religion. Ruby (2016), like Bullock (2000), referencing the Canadian media's portrayal of Muslim women and using the example of a national film board documentary on Sharia law in Canada; shows how Muslim women continue to be depicted in the media and in Canadian society as super-oppressed. This film depicts women as victims of Sharia law; what the film describes as Islamic law (National film Board, 2005). Muslim males are portrayed to be the perpetrators of this oppression; especially in the way they are assumed to force the women to wear the veil. Ruby (2016) refers to this as a sexist and imperialist discourse. Hence, while we know of incidences of extreme and visibly violent 
expressions of islamophobia such as the mosque attack in Quebec (Gravelle, 2018; Laflamme, 2018), very little is known on how else islamophobia manifests itself in Canada. Most of the Canadian literature tends to mention islamophobia in relation to Quebec (Gravelle, 2018; Laflamme, 2018) making it difficult to gage how this phenomenon manifests itself in other provinces. Also, to show incidents of islamophobia many of the authors like Gravelle (2018) mention the biases against the niqab; which is the form of hijab (a veil that Muslim women wear to cover their hair) whereby the face is covered as well except for the eyes. Hence, if one is talking about the niqab, which some Somali women wear also, the question becomes one about how they are negotiating their way in the Canadian labour market.

According to Laflamme (2018), islamophobia did not just begin following the infamous 9/11 attack; such sentiments already existed but were exacerbated. Edward Said's (1979) work on Orientalism demonstrates how misrepresentations of Islam have historical roots (Gravelle 2018; Laflamme 2018). According to Khattab \& Hussein (2018), in recent decades "[t]he global image of Muslims has negatively shifted due to increased levels of Islamophobia on the one hand....and growing resentments among various segments of the population in relation to migration generally on the other hand" (p.1012). This growing islamophobia since 9/11 is bound to affect Somali women, especially those who wear the Hijab.

Literature on islamophobia in the labour market in the Canadian context is rather scarce. Most authors just speak to other implications and manifestations of Islamophobia. Laflamme (2018) states that "although there has been much recent discussion surrounding the issue of islamophobia in Canada, little good-quality empirical data has been systematically analyzed regarding the everyday realities of this phenomenon" (p.87). In order to get a sense of how Muslims are viewed in Canada it is important to look at the literature that surrounds this issue. It 
is stated by Khattab et al. (2018) that, when it comes to economic action and unemployment, they found that, parallel to British Muslims, Canadian Muslims coped well in employment and managed less in labor market participation. The lack of participation of Muslim Canadian women in the labour market is tied to "cultural" explanations where there is a widespread view that the reasons behind the very low participation in the labour market is due to Islamic cultural practices and the "Sharia law" which relegate women to the private sphere (Khattab et al. 2018). This $i$ argue is not accurate when it comes to Somali women in the Canadian diaspora who have often found themselves as single moms here in Canada and therefore have to earn a living (Mohamed, 2007). Contrary to the popular view that Muslim women are controlled by the "requirements" of their religion, Khattab et al. (2018) has found that religiosity does not play a factor in a Muslim woman's participation in the labour market.

These types of invalid assumptions about Muslim women have negative implications for women's experiences and status in the labour market. As Jasmin Zine (2006) observes:

Beyond representational politics the epistemic violence behind these constructs bears material consequences for Muslim girls and women. Studies that highlight the impact of gendered Islamophobia have shown that Muslim women who wear hijab suffer discrimination in the workplace (p.14).

To illustrate this above point Zine points to barriers that affect women in the Canadian labour market. The author uses a study done in Toronto whereby 29 out of 32 women who were interviewed complained that the employers they came across referred to and commented on their veil when they were applying for jobs in manufacturing, sales, and service sectors. Zine (2006) goes on to say that twenty one percent of the interviewees in the study were asked to remove the veil while one third were asked if they could remove their "head covers" if they wanted a job at all (p.14). Zine is one of the few authors who looks into the implications of Islamophobia in the Canadian labour market. In the same study, a group of two sets of women who were similar in 
age, ethnicity and in possession of identical resumes were sent undercover to apply for the same jobs: $62.5 \%$ of the women (who did not wear the Hijab) were given an application to fill out while $12.5 \%$ (who wore the Hijab) were given the same opportunities. (Zine, 2006, p.240). This demonstrates the "nature of gendered Islamophobia as it operates socially, politically, and discursively to deny material advantages to Muslim women" (Ibid, p.240). Many Somali women wear the Hijab which identifies them as being part of the Islamic religion and individuals who are in a position of power in the labour market may use this to deny them a fair chance on a job application. In a study done in the United Kingdom it was also found that White British Muslim women who converted to Islam faced a penalty in the labour market as compared to their white female counterparts in attaining decent salary jobs. (Khattab \& Hussein, 2018). This price they pay can be considered a "Muslim penalty" especially since they wear the hijab.

Khattab and Hussein (2018) talk about the inequality in attainment of professional jobs in places like the United Kingdom and Canada for Muslim women as compared to their white Christian counterparts. Khattab et al. (2018) provides the most up to date literature on Black Muslims which would include Somali women (by the mere fact that they are both categorized as black racially and predominantly Muslim). Hamdan (2007) also points out that the majority of Muslim women are identified as visible minorities and that one in three are likely to be discriminated against as compared to non-Muslim cohorts. In looking at the British example, Black Muslim women earned some of the lowest wages ranking second last at $£ 8.11$ and $£ 8.65$ per hour; with first-generation Bangladeshi women in last place earning the very lowest at $£ 7.37$ (Khattab and Hussein, 2018, p.1016). 


\subsection{Common Assumptions and Biases About Somali Women}

In addition to other representations based on race, gender and religion, the way Somali women are portrayed in Canada also has a lot to do with assumptions based on their migratory status as well as stereotypical media portrayals of Somali people. In her study of Somali women's arrival in Canada as refugees Spitzer (2006) found that many Somali Canadian women were coming from successfully run businesses in their homeland. In speaking about these women in her research Spitzer (2006) states that "their stories of work, wealth and the respect they earned contrasts with the image of Somali women as confined to oppressive households in a poor country lacking in basic amenities" (p.51). This seems to be a recurring theme in the portrayal of women in the Somali diaspora. In Australia Somali women believe "they are subject to discrimination and that their racial identity and migration status are used to justify exclusion" (McMichael and Manderson, 2004, p.63). One Somali woman explained the dominant narrative that every Somali woman in the diaspora deals with, she states:

They see us as someone who had nothing. But the reality is that where we came from, some of us were rich, some of us were normal, and some of us lived day by day. But here to the Australian people's eyes, people think that we were nothing, that we were refugees. That we never owned anything, that we were uneducated. But that is how they see us. But that is not the truth (McMichael and Manderson, 2004, p.95)

Spitzer (2006) makes an important observation that involuntary migration is often seen as voluntary by the Canadian public. In other words, they think that that Somali women or Somali people in general voluntarily chose to come to Canada, not taking into consideration how they were forced out by a civil war, which left them no choice but to leave. Somali women "are cast as not only the great unwashed, but the great unskilled and voluntary migrants, lack of recognition of credentials and work experience contribute to a downward mobility that is difficult to reverse, particularly for women of colour who are relegated to the lowest ranks of the 
Canadian workforce" (Spitzer, 2006, p.51). These stereotypical portrayals are not only experienced by Somali women but by all women of African descent. This is due to media portrayals of Africans as hunger-stricken and living in the wild. This does not take into consideration that they come from sophisticated societies and can make significant contributions to the Canadian labour market. In Somalia many of these women had professional jobs. Contrary to media depictions, Somalia before the civil war was a thriving country. Spitzer (2006) points out that despite such portrayals leading to the socio-economic disadvantages, Somali refugee women have found ways to cope. One of these coping mechanisms is known as hagbad, loaning circles that has helped these women survive financially (spitzer, 2006). In the hagbad system eight to ten women put money into a monthly pool within a span of a year and in a rotating system each woman from the loaning circle collects the money. This is in total contradiction to the "welfare queen" portrayals of Somali immigrant women as they try to protect themselves socio-economically.

As mentioned above, Somali women and Somali people in general have been viewed as being welfare recipients and as dependents who drain the resources of the Canadian economy and the state (Spitzer 2006). This perspective is not just negatively biased, but it is also especially problematic as it involves no understanding of the disadvantages and challenges these women have confronted. Somali immigrant women have had to adjust to life In Canada as refugees, with no language skills for most and very little integration assistance from the government. Hence, most found themselves helpless and on social assistance. Although there is some literature on government policies and their impact on what has happened to these women after their arrival (Spitzer 2006, Danso, 2002), as well as the trauma they experienced before and after the journey to Canada (Bokore, 2017), the literature is lacking on their labour market 
experiences. The literature on Somali women in Australia suggests that "few Somali women, consider themselves as part of a wider Australian Community: their neighbours do not speak the same language, some people are unwelcoming, the culture of Anglo Australians is less communal than in Somalia, and their own religious beliefs and language set them apart" (McMichael and Manderson, 2004, p.95). These same sentiments were echoed by Somali women in the Netherlands who complained about being stared at when it came to how they dressed. Even going to events and changing themselves so as not to appear different did not help (Liempt, 2011). Hence, such biased portrayals of Somali women can potentially affect their access to the Canadian labour market.

\subsection{Social Networks, Social Capital and the Labour Market}

Social Networks leading to social capital is crucial for newly arrived immigrants and refugees in accessing the labour market. McMichael and Manderson (2004) suggest that formal social networks such as community organizations, "can enhance a sense of belonging among new settlers and provide them with resources, addressing immediate concerns for housing and employment" (p.88). Research in Toronto by Danso (2002) underline the significance of social networks, especially in the absence of government assistance:

Confronted with constrained access to official counselling services and orientation programs, many Ethiopian or Somali immigrant have been forced to look 'inward' and rely heavily on ethnic networks for information on employment, housing, education, and language training programs even though the ethnic communities per se are not in a very strong position to help their own members. Social networks were thus, and continue to be, the mainstay of information for Ethiopians and Somalis in Toronto. The public sector seems to offer limited hope in this regard. (p.13)

Consequently, race, religion and gender are not the only challenges that Somali women experience. They also have other barriers such as non-existent or weak social networks that 
inhibits their attainment of social capital. A report done by statistics Canada emphasizes the relationship between social connections and social capital, whereby social capital is defined as the benefits one gains from networks of family, friends and acquaintances (Hudon, 2015, Statistics Canada). Li (2004) expands the definition by adding that "social capital has two components: (a) social relationships that people inherit and cultivate in a social context; and (b) the potential resources of these relationships that people may use to pursue social and economic goals" (p.172). Hudon (2015) argues that such a group can be diverse and can help Somali immigrant women create networks across various lucrative sectors within the labour market giving them access to well-paying jobs. Behtoui and Olson (2014), assert that when it comes to integration, some communities do not have the benefit of access to already-established social networks upon arrival to the new country:

In some cases, arriving in a new country, an immigrant family can utilize a network of kin, friends and compatriots who act as a supporting 'community'. In other cases, immigrants are the first group in the new country; hence, they have to cope alone with the difficulties of the first stage of migration. (Behtoui and Olson p.781)

This is the case of Somalis who arrived in Canada in the 1980s for the very first time in their new host country. In addition, it was found that immigrant women in general have fewer connections as compared to their Canadian counterparts (Hudon, 2015, Statistics Canada).The exact figures when it comes to the different ratios of immigrant women to Canadian born women in terms of access to social capital is 24 social networks on average for immigrant women, as compared to 29 social networks for Canadian born women (Hudon, 2015, Statistics Canada, p.33). Focusing on immigrant women in general these statistics do not take into consideration that Somali women have even fewer chances in accessing networks within the labour market leading to social capital. 
Somali immigrant women left behind social connections when the civil war broke out. Somali women in Australia attribute the loss of social capital not only to war but to their arrival in a new country where employment opportunities are scarce. Hence, the social capital gained from networks is eroded whereby the majority of the women are forced to go on welfare where "financial constraints also undermine women's ability to maintain social ties and a sense of community...conditions of scarcity assail sources of assistance and set the conditions by which mutual obligations and exchange are limited" (McMichael and Manderson, p.94). The context is somehow different in other diaspora nations like the United Kingdom where Somalis had arrived in the early twentieth century via seamen (in places like Cardiff), giving new immigrants and refugees access to social networks that were already established. This lack of social capital is yet another barrier that Somali immigrant women must contend with and sets them back as compared to their non-racialized counterparts in Canada who use their networks to gain access to well-paying professional and managerial jobs.

\subsection{Gender, Social Reproduction and Relationship to the Labour Market}

Just because women are not in the labour market and identify as unemployed does not mean they are not contributing to the economy. The majority of working women are still responsible for household duties. This contribution that women make daily is known as social reproduction of labour, and Jackson and Thomas (2017) describe this as involving:

the wide range of activities and relationships involved in maintaining people on both a daily basis and intergenerationally, such as buying household goods, preparing meals, washing, repairing clothes, cleaning the house, raising children, providing emotional support for children and adults (p.93)

Jackson and Thomas (2017) point out that this type of labour is crucial if the formal labour market is to function at all. It is also noted that bearing the main responsibility for social reproduction of labour is one of the major reasons that women are overrepresented in 
substandard and precarious work (Jackson and Thomas, 2017). The authors mention that often times employers are not sympathetic to the plight of these women who have multiple responsibilities between taking care of their households and working at the same time. This helps explain the gender wage gap between men and women and the continuous economic inequality between the two genders (Ibid).

The situation for Somali women is even more difficult as they not only have to juggle these domestic duties but also continue to adjust to their lives in a host country and try to earn a living at the same time. This is especially challenging since most Somali women did not struggle as much when it came to duties within the private sphere such as childcare and other domestic work in their country of origin. Rather they could rely on their kin as well as help from domestic workers (Spitzer, 2006). This is also corroborated by Premji et al. (2014) whose study of racialized women found that "without the social support system they used to have in their country of origin, most of the household and caregiving responsibilities fell solely on them" (p.131). To make matters even more difficult, these women have difficulty finding childcare they can afford (Premji, 2014). In addition, Somali women are often single mothers (Mohamed, 2007). These women, who are mostly first-generation, are struggling to make it in their new host country when their youth (mainly young men) are engaging and are caught up in gun violence, with many losing their lives (CBC News, 2019). As Jackson and Thomas (2017) point out, social reproduction of labour is much different between racialized women and non-racialized women; the former in a far more challenging position whereby they find themselves in "highly precarious and exploitative" conditions (p.93).

Depiction of Somali refugee women as "welfare queens" has been especially unfair considering the multiplicity of pressures involved in maintaining the household as single parents 
and as refugee women themselves and their families are undergoing adjustments to life in a new country (Warfa et al.2012). The term is unfair, and no group of people deserve to be stigmatized in this way.

\subsection{Settlement Policies and Practices of the Canadian Government}

At the time of arrival of Somali refugees, the Canadian Government did not take into consideration that Somali women were less likely to be in possession of formal identification, especially the near impossibility of obtaining these documents at the peak of the civil war (Spitzer, 2006). It is not just Somali women that are confronted with this problem. It is estimated that eighty percent of refugees who do not possess identity documents are often women and children (Spitzer, 2006). Despite this evidence, the Canadian government in 1993 passed Bill C86 which called for a five year wait time for those with no identification to gain permanent residency (Spitzer, 2006). The delayed process meant that family reunification was impossible meaning that loved ones were still caught up in a dangerous situation back home and in camps; thus adding to the stress of post-migration. Also, the lack of permanent resident status meant that children had to delay attending post-secondary education since parents could not afford tuition due to the fact that they did not qualify for loans and bursaries (Spitzer, 2006). In terms of the labour market, this lack of government assistance has been an ongoing problem as articulated by Premji et al. (2014): "immigrant women specifically those from racialized backgrounds have largely been missing in policy framing and public debates about labour market and economic issues in Canada" (p. 124).

Government policy can put an end to some of these barriers by engaging in issues that affect racialized women and encouraging the private sector to follow their example. Such policies as proper integration (just to name a few) in advising the employers that foreign 
credentials should be honoured could have made a big difference in the lives of Somali women. The lack of commitment from the government when it comes to the labour market goes against principles and policies of the Canadian Charter of Rights and Freedoms, Multiculturalism Act and Employment Equity Act means inequality based on race, religion and gender continues in Canada. Authors Behtoui and Olson (2014) substantiate Spitzer's (2006) point that government institutional as well as the Canadian civil society's lack of acceptance and suspicion of Somali women as refugees at the early outset played an important part in integration. Specifically, they state that governments do discriminate between different nationalities, allowing some smooth entry into the host country while others are left to linger and deal with bureaucratic red tape.

The literature (Bokore, 2017, Spitzer, 2006,) reveals that no matter which host nation Somalis ended up in as refugees, their credentials were not honoured (Bokore, 2017; Spitzer, 2006). In the Canadian context, author after author mentions unemployment and underemployment (based on nonrecognition of credentials) especially in early migration, to be the biggest obstacle faced by immigrant communities of colour. Danso (2002) states:

There is a general lack of recognition in Canada of the professional qualifications, credentials, and training of visible minority immigrants in the urban job market in Canada. Immigrants' credentials tend to carry a penalty compared to those of native-born Canadians; a foreign degree affects visible minority immigrants, women, and men more adversely than white Canadians. (p.10)

It is these types of barriers that plagued Somali women in the Canadian labour market placing them at the bottom of the socio-economic ladder. If the credential issue had been remedied early in the settlement process, Somali women would not have been so vulnerable to poverty. 


\section{CONSEQUENCES OF UNFAVOURABLE LABOUR MARKET OUTCOMES:}

\subsection{Racialization of Poverty}

A direct result of labour market exclusion for racialized women such as Somali women is the phenomenon of racialization of poverty. Racialization of poverty is defined by Grace Edward Galabuzi and Block (2011) as: "a phenomenon where poverty becomes disproportionately concentrated and reproduced among racialized group members, in some cases intergenerationally" (p. 15). This phenomenon is demonstrated by statistics which show that in Canada in $2005,6.4 \%$ of non-racialized families lived in poverty as compared to $19.8 \%$ racialized families in 2005 (Galabuzi and Block, 2011, p.15). This is due to the wage gap, precarious employment and unemployment amongst racialized communities. Somalis are "prominent in the statistics of poverty..." making them even more vulnerable (Bokore, 2017, p.146). This is corroborated by Danso (2002), who found in his study of Toronto, Ontario, that:

Somalis face significant barriers during the initial stages of their new life in Toronto. Analysis has identified five major barriers all of which are closely related: unemployment or non-recognition of credentials, language barriers, racial discrimination, housing market constraints, and insufficient income. These have contributed in a great measure to the very high levels of poverty. (p.12)

According to the Organization for Economic Cooperation and Development (2008) figures poverty increased in the OECD between the mid-1990s to mid-2000s, especially with the increase of precarious employment (Lightman and Gingrich, 2018). Amongst OECD countries, Canada "is the country with the highest rate of poverty for non-standard workers (35\%, compared to an OECD average of 22\%)" (Ibid, p. 35).

In addition to unemployment, underemployment and precariousness in the labour market, Somali women are dealing with environmental stressors living in precarious housing and 
neighbourhoods where there are high crime rates. Statistically, Bokore (2017) found that out of all the multiple participants in her study only two Somali women did not live in ghettoized neighbourhoods with high crime rates (p.152). In a study by MacDonnell et al (2012), "women who came from war zones talked about similarity of marginalized neighbourhoods in Toronto to the war zones they came from" (p.7). Poverty eradication should be the utmost priority by the Canadian government.

\subsection{Health of Somali Women}

Somali women can attribute the deterioration of both their physical and mental health to their labour market status which then contributes to their low socio-economic ranking in Canada. When it comes to physical health, Spitzer (2006) links deterioration of Somali-Canadian women's health to the policies enacted by the Canadian government as well as the inequality that these women encountered in the labour market. Mistrusted by the bureaucratic suspicion of refugee determination policies, women have had to endure longer wait times for permanent residency. Hence, they found themselves developing diseases and conditions that were stressinduced. A study done of Somali women in Toronto, Ottawa and Edmonton reported that these women complained of illnesses such as type- 2 diabetes, hypertension, high cholesterol levels and high blood pressure (Spitzer, 2006). According to the author these diseases and conditions were related to "uprooting and resettlement" (Spitzer, 2006, p. 51). The "waiting game" caused by delayed processes of refugee determination and permanent residency caused delays in family reunification and delivery of some settlement services leading to increased hardship and stress. Diseases such as these were preventable, if only such policies were fair to these women. Warfa et al. (2012), state that another contributor to ill health for Somalis in general not just for Somali women is and was the: 
perceived stigma attached to an existence as a refugee contributed to the sense of disillusionment and powerlessness...it was not only the unemployed or those with language problems and limited skills who find It difficult to integrate to the host nations, but also participants with professional skills who were fluent in English and were in a better position to take control of their lives. They too felt that lack of recognition of their existence and previous professional skills and talents prevented them from achieving satisfactory integration, with associated risks of psychological distress (p.10).

Therefore, there is a direct link between underemployment and health. One woman in a focus group stated "you have to do two or three jobs to maintain family...rent which is high. You cannot afford to buy proper food, to eat proper food, the time to eat. Then you end up having high blood pressure, diabetes, high stress" (MacDonnell et al. 2012, p.7). Hyman (2009), in citing Galabuzi (2004), uses the latter author's argument “that there is a need to account the health impacts of institutional racism i.e., not having equal access to social, economic, political, and cultural systems that determine the distribution of society's resources due to racial or ethnic characteristics" (p.10). Hyman (2009) cites Galabuzi \& Teelucksingh (2007), who link this issue to determinants of health:

differential treatment in recruitment, hiring and promotion, extensive reliance on nontransparent forms of recruitment, such as word of mouth, which reproduce and reinforce existing networks, differential valuation or effective devaluation of internationally obtained credentials and use of immigrant status as a proxy for lower quality of human capital, contribute to differential outcomes in the labour force (p.10)

In addition to physical health, Somali women and racialized women often complained of the deterioration of mental health. Macdonald et al. (2012), in their focus group research of Somali women and marginalized immigrant women, have found that " social determinants of health such as social exclusion, racism, employment, and poverty have been linked to immigrant women's wellbeing...mental health implications of settlement...employment certification processes...and gender is implicated in these migration processes" (p.2). What exacerbates the situation is stigma about emotional and mental illness that is prevalent not only in the Somali 
community but in Canadian society as a whole. This makes getting treatment difficult and it complicates the success of treatment.

Premji and Shakya's (2017) analysis of the link between unemployment, underemployment and health for racialized women point to the fact that "[u]nemployment has been found to lead to poor mental and physical health through pathways that include lack of income, loss of status and self-esteem, reduction of physical and mental activity, and unhealthy behaviors and coping strategies" (p.18). Racialized women's over-representation in precarious work puts them at high risk of developing both physical and mental ailments this is due in part with the lack of rights and security in the jobs they are undertaking (Premji and Shakya, 2017). Specifically, Premji and Shakya (2017) argue that

precarious employment, which broadly refers to high levels of job insecurity, has been shown to negatively impact health through mechanisms that include greater exposure to risks; fewer protections and opportunities for training; absence of benefits; lack of compliance with and enforcement of legislation; limited agency; and work-life conflict (p. 18)

Women whose credentials were not recognized and therefore had trouble finding work felt "devalued" (Premji and Shakya, 2017, p.23). The health of these women's families was also affected, especially in their inability to "pay rent and bills, buy clothes, food, medication, and save for emergency situations or old age" (Ibid, p.24).

Immigration and settlement researchers have identified a phenomenon known as the "healthy immigrant effect". They argue that the health diagnosis of an immigrant is good upon arrival to Canada but that it then deteriorates over time. More specifically, the "healthy immigrant effect" is defined as "an observed time path in which the health of immigrants just after migration is substantially better than that of comparable native-born people but worsens with additional years in the new country" (McDonald and Kennedy, 2004, p.1613). This theory 
is consistent with what has happened to Somali women upon arrival in Canada especially in terms of their physical health. One woman who was interviewed by Bokore (2017) after an Islamophobic incident whereby a bottle was thrown at her from a moving vehicle stated, " I drive everywhere which is not helping my blood pressure and weight problem. I need to exercise but I can't afford female-only gyms and I can't walk on the street or park because of fear" (p.152). Other Somali women in the author's study also talked about the mental impact of Islamophobia and racism and how experiencing them triggered the past trauma from the civil war the refugee women had left behind (Bokore, 2017).

\section{DISCUSSION AND CONCLUSION}

It is clear therefore, and many scholars within the wide literature agree, that non-racialized women and men are at the top of the labour market and have access to professional and managerial jobs. In addition, Somali women like their fellow immigrant racialized women are experiencing difficulties in the labour market in their susceptibility to precarious work due to lack of credential recognition in early settlement; despite the fact that they were often highly educated and often possessed competitive sets of skill. From the literature one finds that Somali women had to confront assumptions about their immigrant, Black, Muslim, and gender identities; as well as adjusting to the countries that they immigrated to. Despite all these challenges, Somali women have continued to be resilient through their formation of communities and loaning circles. One of the leading barriers in the labour market commonly experienced by all immigrants and refugees is the "Canadian Experience" requirement (Danso,2002). This is a highly contentious subject that has kept many qualified racialized immigrants from attaining professional jobs. In a focus group in Ontario whose participants included Somali women, found 
that the most common barriers were in education, housing, employment and credentialing (especially in early arrival).

Overall, it was also found that Somali Muslim women alongside all their female Muslim counterparts have trouble attaining jobs, a good salary and are more likely to be in the unemployment lines (Khattab \& Hussein, 2018). Hence, when it comes to Somali women it was demonstrated that they are now mostly the sole providers within the household (Mohamed, 2007). Alleviating their struggles should be part of solidarity and humanitarian ideals that Canada prides itself on. As Nimo Bokore (2017) points out the Somali community is noticeable in the statistics on poverty and violence in Canada. Like their mothers' young people are experiencing racism, Islamophobia, labour market barriers and lack of government programs to support their transition (Bokore, 2013).

In addition, this is an important topic in the field of migration in the Canadian context, in that as a country Canada fulfilled its first obligation in welcoming Somali refugees especially women, however it did not go further in assisting them with the integration process. Hence, a lot of these women suffered on their own. There was and still is a major contradiction in the way these women were viewed and still are viewed as "welfare queens," yet at the same time their credentials which could have allowed them to enter the labour market was not valued. In the community however, positive things are starting to be witnessed and that is the secondgeneration (mainly girls) are beginning to pursue a higher education and in turn alleviating the socio-economic pressures that their first-generation Somali mothers who first stepped foot on Canadian soil are experiencing. In addition, there has been a lack of policy framing from the Canadian government to assist racialized women with any socio-economic issues (Premji et al. 2006, Bokore, 2017). Furthermore, low pay is the reality for many women as well as the gender 
pay gap which is highly problematic for both economic and equality reasons. Also, the Census needs to be mandatory again so we may assess the socio-economic status of the Somali community to which the Somali women belong.

When it comes to the issue of health, one of the solutions offered by Jones (2015) is that "in order for black women to achieve psychosocial wellness, they need safe spaces where they can share their stories, be heard, recover from psychosocial traumas, and create strategies for change. These spaces often exist in contexts where black women feel free to sort out their personal struggles from structural constraints of racism, sexism, classism..." (p.246). Black feminists call for the change in perceptions when it comes to Black women's health. They specifically ask for dialogue on issues such as racism that surround these women on a daily basis. They suggest that conferences, literature and that discourses of social practitioners should allow black women to "re-story their identified problems without feeling invalidated or dismissed" (Jones, 2015, p.250). The long-term consequences of decades of marginalization mean that there is a need for health care resources that meet the specific needs of the community. As mentioned, Somali immigrant women are struggling both with their mental health and physical health.

\subsection{Survival and Resilience in an Unwelcoming and Unequal Environment}

The lack of support that Somali women have faced from the government as well as weak social networks when it comes to addressing the barriers in the labour market; have meant that Somali women had to be resilient through the formation of community economic/social enclaves and loaning circles. This lack of support can be seen through the governments minimal and rather ineffective role in addressing the multiplicity of inequalities faced by racialized immigrant women. Moreover, Dr. Galabuzi (2006) speaks to the government's minimal attempt in 
addressing the issue of racial inequality vis a vis the Multiculturalism Act and the Employment Equity Act; both of which have been insubstantial:

1971 The multiculturalism Act: has not addressed issues of racial discrimination instead it implies a form of neutral diversity and harmony among equals. The 1986 Federal Employment Equity Act reports show that progress made after 15 years has not matched the growth in the numbers of racialized group members in the Canadian population. Most experts have suggested that the weak enforcement regime is to blame (p.217)

The only settlement service provided by the Canadian government at the beginning was language assistance. Hence, except for indirect help (through ethnic organizations), most racialized communities, such as the Somali community, were left alone in the resettlement process (Danto,2002). The reports of minimal help from the Canadian government appeared frequently in the literature.

A reoccurring theme in the literature is the resiliency of Somali women and women of colour. Resiliency is best defined in MacDonnell et al. (2012), as "the capacity to cope with, and bounce back after, the ongoing demands and challenges of life, and to learn from them in a positive way" (p.7). Everywhere in the diaspora, Somali women have faced the hardships and discrimination based on Islamophobia, racism, gender and day to day struggles within the labour market (such as lack of early credential recognition) with resilience. Whether it is loaning circles as mentioned before (also known as hagbad) or celebrations, these women have banded together (Spitzer, 2006, McMichael and Manderson, 2004). Hence, "social events, religious gatherings, and celebrations play an important role in women's lives, promoting interaction, shared time and a sense of wellbeing" (McMichael and Manderson, 2004, p.96). These women do not pity themselves and do not want to be pitied. Rather, they have shown through their resiliency that they can overcome major systemic deficiencies. This resiliency is also shared by other groups of 
racialized women. When they encounter precarious employment, "they considered it as temporary and were highly motivated and strategic in planning their upward mobility in an effort to gain entry into administrative, managerial and professional occupations" (Das Gupta et al. 2014, p.67).

Another form of resiliency by Somali women is through formation of ethnic communities. There seems to be a pattern whereby when the labour market becomes tough, migrant communities segregate themselves into communities as a form of survival. Liempt (2011) argues that when a community separates themselves from other groups within the host nation it does not impede upon their labour market chances as is commonly assumed and argued by others:

The oft-heard critique that spatial segregation of immigrant groups can impede language acquisition, educational achievement and labour market integration overlooks the fact that the strength of the community can actually also facilitate integration into the country (Liempt, 2011, p.3393-3394)

Ethnic communities create a space where people feel comfortable setting up entrepreneurship leading to smooth integration into the host nation by offering "occupational and social mobility"(Liempt, 2011, p.3394). As mentioned earlier in the paper, an example of such community support can be found in Toronto called Suuqa Ceelgaab; which is essentially a Somali flea market. These types of community enclaves have allowed first-generation Somali women the chance to earn a living in the informal sector. These women have stalls where they sell goods such as traditional Somali clothing (i.e. diraaq) and religious clothing (i.e. abaya) and many other goods and services aimed at their religious and ethnic community. This has provided these women with a livelihood alternative to the tough Toronto labour market. Investing in such community enclaves by the government and private corporations could really help these women develop their businesses even further by making them economically viable. 


\subsection{Towards an Inclusive Labour Market for Racialized and Gendered Immigrants}

The presence of a racialized and gendered systemic discrimination in Canada's labor market has been clearly demonstrated by data (Lightman and Gingrich, 2018). Shutting racialized immigrant women out of more skilled and professional positions in the labour market not only increases their invisibility, but also constitutes a loss of skills and potential for employers and the Canadian economy (Das Gupta et al., 2014). If the situation in the labour market is to improve, Somali women must assert themselves in the political and organizational climate. Statistics Canada has found that immigrant women were less likely to vote or be part of an organization as compared to Canadian born women (Hudon, 2015). If this is the case, there will be no one to advocate for them in terms of inclusivity or assist with the barriers they face in entering the labour market.

Galabuzi (2006) talks about the importance of a multi-sector approach to address the problem of racial discrimination. He suggests that all levels of government and other institutions in civil society should reach out to racialized communities. Galabuzi (2006) states that institutions such as the media, labour market and government institutions have to deal with the issues of racial inequality before the situation of vulnerable racialized communities gets worse. Danso (2002) also talks about the importance of a settlement package that includes both the private and public entities i.e. family and social networks as well as the Canadian government, that ultimately assist racialized immigrant communities. Galabuzi (2006) has a program of action:

a) Employment equity: The need to "remove barriers to access of employment...mandatory employment equity programs should be introduced to deal with the failure of the marketplace to equitably allocate employment opportunities and incomes"; (p.228) 
b) Strengthening employment standards..."removal of abuse by unscrupulous employers" (p.229);

c) Developing a national urban strategy: Development of urban centres to discuss issues of "persistent inequality in the labour market, urban poverty, and racialized poverty" (Ibid, p.229);

As pointed out by Danso (2002), "[b]oth financial security and economic independence are bedrocks of any meaningful integration in a western industrialized society like Canada" (p.10).

Saloojee (2009) also offers solutions against discrimination and inequalities in the form of "anti-racist social inclusion":

from anti-racist perspective, an inclusive society is one that, at a minimum; develops the talents and capacities of all its members;...eradicates all forms of poverty, including racialized poverty; promotes democratic citizenship; strengthens organizations in civil society that represent disadvantaged communities; ... eradicates the racially split labour market; eliminates barriers to labour market participation by members of racialized communities (Saloojee, 2009, p. 3).

Danso (2002), who did an extensive study on Somali and Ethiopian community speaks to the fact that these communities feel let down by what Canada promised as their new host country:

The discrimination and marginalization they have endured have convinced many Ethiopian and Somali newcomers that the country that promised them a new lease on life has somehow failed them and that it might not be the place for them to rebuild their lives. Consequently, there is a very high level of nostalgia within the communities with many people expressing a strong desire to return to the homeland were conditions to improve today. (p.12)

Henceforth, the Implications of a marginal status in the labour market is a racialized experience of poverty that leads to " social alienation, powerlessness, marginalization, voicelessness, vulnerability and insecurity both in the workplace and in the community" (Galabuzi and Block, 2011, p.4). Galabuzi and Block (2011) make a very important point that "if the labour market continues to relegate racialized groups to the back of the pact, the number of Canadians left 
behind will only accelerate-calling into question the promise that Canada as a fair and caring society committed to equal opportunities, no matter who you are and where you come from"(Ibid, p.4).

After almost three decades of settling in Canada, Somalian immigrant women's experiences suggest that there is still a lot that needs to be done by the Canadian state. First, as already mentioned, these women did come with significant credentials from Somalia that clearly should have been honoured. Hence, had accreditation been the norm, not the exception at the early outset for these women they would not have lagged behind in the labour market. In addition, there needs to be labour market integration. As was seen throughout this paper these women have been marginalized economically and the above-mentioned recommendations would have and can still assist them. Also, Canadian policymakers need to rethink multiculturalism. Multiculturalism acts as a mask and does not deal with deeper issues such as racism and Islamophobia prevalent in Canadian society. Bokore (2017) calls for a "bi-dimensional integration", that is a collaboration between those settling in a host nation with those that are welcoming immigrants or refugees. In other words, an integration process that considers the everyday issues and obstacles of those settling in the country in conjunction with government /settlement agencies. This is an excellent idea because each group of refugees and immigrants have their own distinct attributes and proper integration needs to take this into account.

As is pointed out by Thomas and Jackson (2017), social reproduction is something that government policies and practices must take into consideration especially since "the impact of gendered divisions of unpaid labour on women's experiences and opportunities in the workforce cannot be overstated. Almost everywhere, the gap between the employment rates of women and men increase with the presence and number of children in a family" (p.93) Hence, it is clear there 
needs to be an alleviation of such barriers on women in general not just Somali women, by putting into place a nationally funded and affordable child care. It is important to mention that although their gendered roles in social reproduction do not inhibit women from paid work, it sets them back to the point where they take on more precarious and insecure jobs (Jackson and Thomas, 2017). Since Somali women are often in single parent households, the low pay and precarious work puts them deeper into poverty. Therefore, understanding these issues surrounding immigrant Somali women can assist settlement agencies and policy makers for the betterment not only for Somali women but all immigrant women of colour.

\subsection{Future Research}

There is very little research on Somali women's experience in Canada. The literature that exists focuses on trauma and its effects on settlement. The literature lacks in identifying the effects of racism and islamophobia on Somali women; especially in pertaining to the labour market. In addition, primary research on Somali Canadian immigrants on their day to day experience on the above-mentioned topics is rare and needs expansion. In addition, it is important to mention that

$"$ there is limited evidence on the full range of impacts of current trends in the labour markets on racialized immigrant women" (Ibid, p.124).Moreover, Intergenerational labour market experience may vary between the first-generation and second-generation Somali women and the barriers they may face, making it an issue for future study. Also, although there is research on issues of lack of credential recognition there is a gap in the literature on the effects on Somali women in the labour market. Somali women's position in the Canadian labour market is an area that is highly understudied. Future research also needs to account for the type of sectors that Somali women are part of within the Canadian labour market; since all that is known is that due 
to lack of credential recognition, they had to employ economic survival mechanisms in the form of small entrepreneurial activities.

Furthermore, another source of stress for Somali women as well as racialized immigrant women are the transnational responsibilities to family back home (Premji and Shakya, 2017). In the case of Somali women, this comes in the form of remittances. Anne Lindley (2009) reiterates the last point that "despite anecdotal evidence of migrants working long hours in several jobs to send money, the repercussions of remitting for migrants remain under-researched" (p.1317). In addition, according to Lindley (2009), "poverty maybe reinforced by remitting...however it is clear that many remitters are employed in low-paid jobs and are unlikely to have large amounts of disposable income" (p.1326). Henceforth, these are all issues that require further study. 


\section{REFERENCES}

Ad- Dab'bagh, Y. (2017). Islamophobia: Prejudice, the psychological skin of the self and

large - group dynamics. International Journal of Applied Psychoanalytic Studies, 14(3), 173182.

Armstrong, Pat, and Armstrong Hugh (2010). The Double Ghetto: Canadian Women and their segregated work. 3rd Edition. Oxford University Press: Toronto.

Behtoui, A., \& Olson, E. (2014). The performance of early age migrants in education and the Labour market: A Comparison of Bosnia Herzegovinians, Chileans and Somalis in Sweden. Journal of Ethnic and Migration Studies, 40(5), p.778-795.

Bokore, N. (2018). Historical Trauma, resettlement and Intervention Strategies: An Analysis of Somali Canadian experiences. International Migration, 56(2), 146-162.

Bokore, N. (2013). Suffering in silence: A Canadian Somali case study. Journal of Social Work Practice, 27(1), 95-113.

Borjas GJ (1994) The economics of immigration. Journal of Economic Literature 32(4): 16671717.

Brown K (2006) Realizing Muslim women's rights: The role of Islamic identity among British Muslim women. Women's Studies International Forum 29: 417-430.

Browne, I., \& Misra, J. (2003). The intersection of gender and race in the labor market. Annual Review of Sociology, 29(1), 487-513.

Bullock K. H \& Jafri G, J. (2000) Media (Mis) representations: Muslim Women in the Canadian Nation. Canadian Women Studies, 20 (2), 35-40. 
Canham \& Maier (2018). Women bankers in black and white: exploring raced, classed and gendered coalitions Social Dynamics, Vol. 44, NO. 2, pp. 322-340.

CBC News (2019 July 31st). "Gun violence a 'crisis' in Toronto, Somali mothers group says." Retrieved from: https://www.cbc.ca/.../toronto/toronto-police-services-board-somalimother.

Chiswick BR (1978) The effect of Americanization on the earnings of foreign-born men. The Journal of Political Economy 86(5): 897-921.

Collins PH (1999). Black Feminist Thought: Knowledge, Consciousness and the Politics of Empowerment. London: HarperCollins. 2nd ed.

Collins, Hill P. (2000). Black feminist thought: Knowledge, consciousness, and the politics of empowerment (Rev. 10th anniversary ed.) Routledge.

Collins, Hill P. (2015) Intersectionality's Definitional Dilemmas. Annual Review. Sociology. 41:1-20.

Gupta, T. D., Man, G., Mirchandani, K., \& Ng, R. (2014). Class borders: Chinese and south Asian Canadian professional women navigating the labor market. Asian and Pacific Migration Journal, 23(1), 55-83.

Danso Ransford (2002). From "There to Here": An investigation of the initial Settlement experiences of Ethiopian and Somali refugees in Toronto. Geojournal. Vol. 56(1), pp.314.

Galabuzi, G.E. (2004). Social Exclusion. In, D. Raphael (ed.). Social Determinants of Health: Canadian Perspectives. Toronto: Canadian Scholars Press Inc. pp.235-251. 
Galabuzi, G. E. (2006). Canada's economic Apartheid: The Exclusion of Racialized groups in the New Century. Canadian Scholars Press, Toronto.

Galabuzi and Teelucksingh (2007). "Working Precariously: The impact of Race and Immigrant Status on Employment Opportunities and Outcomes in Canada." In Race and Racialization: Essential Readings, First Edition. Editors: Gupta, James, Maaka, Galabuzi and Anderson. Canadian Scholars Press Inc.: Toronto.

Galabuzi \& Block (2011). Canada's Colour Coded Labour Market: The Gap for Racialized Workers. Retrieved from: The Wesley Institute.

Geddes A (2014). The EU, UKIP and the politics of immigration in Britain. The Political Quarterly 85(3): 289-295.

Gamey, D. L. (2013). Islamophobia and the question of Muslim identity: The politics of difference and solidarity by Evelyn Leslie Hamdon (review). Canadian Ethnic Studies, 45(1), 268-270.

Gravelle, T. B. (2018). Friends, neighbours, townspeople and parties: Explaining Canadian attitudes toward Muslims. Canadian Journal of Political Science, 51(3), 643-664.

Hamdan, A. (2007). Arab Muslim women in Canada: The untold narratives. Journal of Muslim Minority Affairs, 27(1), 133-154.

Hudon, Tamara (2015). Immigrant Women in Canada a Gender Based Statistical Report. Retrieved from Statistics Canada: https://www150.statcan.gc.ca/n1/en/pub/89503x/2015001/article/14217-eng.pdf?st=G-t2NT4

Hyman Ilene (2009). Racism as a Determinant of Immigrant Health. Paper presented at March 30th, 2009 Metropolis conference. Retrieved from: http://www.metropolis.net/pdfs/racism_policy_brief_e.pdf 
Jackson, Andrew and Thomas, Mark, P. (2017). Work and Labour in Canada: Critical Issues, third edition. Canadian Scholars: Toronto.

Jesow, S. (2016). Analysis of Social Networks, Exclusion and Economic Participation of Somali Immigrant Women in the GTA. Issue 5. Retrieved from: https://carleton.ca/africanstudies/wp- content/uploads/4-Nokoko-5-Jesow.pdf

Jones Lani V. (2015) Black Feminisms: Renewing Sacred Healing Spaces. Journal of Women and Social Work. Vol. 30(2), p.246-252.

Khattab Nabil, Sami Miaari, Marwan Mohamed Ali, Sarab Abu-Rabia Queder (2018). Muslim Women in the Canadian Labor Market: Between Ethnic exclusion and Religious discrimination. Elsevier: Research in social Stratification and Mobility. In Process: received on July 17, 2018.

Khattab and Hussein (2018) Can Religious Affiliation Explain the Disadvantage of Muslim Women in the British Labour Market? Work, Employment and Society, Vol. 32 (6), pp. 1011-1028.

Koopmans R (2016) Does assimilation work? Sociocultural determinants of labour market participation of European Muslims. Journal of Ethnic and Migration Studies 42(2): 197-216.

Laflamme, Sarah Wilkins. (2018) Islamophobia in Canada: Measuring the Realities of Negative Attitudes Toward Muslims and Religious Discrimination. Canadian Sociological Association.

Li, P. (2004). Social Capital and Economic Outcomes for Immigrants and Ethnic Minorities. Journal of International Migration and Integration, 5(2), pp.171-190. 
Lightman, Naomi (2018). Measuring Economic Exclusion for Racialized Minorities, Immigrants and Women in Canada: Results from 2000 and 2010. Journal of Poverty, Vol.28, No.5, pp.398-420.

Lindley, A. (2009). The early-morning phone call: Remittances from a refugee diaspora perspective. Journal of Ethnic and Migration Studies, 35(8), 1315-1334.

Liempt, I.V. (2011). From Dutch Dispersal to Ethnic Enclaves in the UK: the relationship between segregation and integration examined through the eyes of Somalis. Urban Studies. Vol. 48 (16), pp.3385-3398.

Luxton, Meg, and Corman, June. 2001. Getting by in Hard Times: Gendered Labour at Home and on the Job. University of Toronto Press: Toronto.

MacDonnell Judith A., Dasterji Mahdia, Bokore Nimo and Khanlou Nazilla (2012). Becoming Resilient: Promoting the Mental Health and Well-Being of Immigrant Women in a Canadian Context. Nursing Research and Practice Vol.2012.

Man G (2004) Gender, work and migration: Deskilling Chinese immigrant women in Canada. Women's Studies International Forum 27: 135-148..

McDonald, J. T. \& Kennedy S. (2004). Insights into the 'healthy immigrant effect': health status and health service use of immigrants to Canada. Social Science and Medicine Vol.59, pp1613-1627.

McMichael, C., \& Manderson, L. (2004). Somali women and well-being: Social networks and social capital among immigrant women in Australia. Human Organization, 63(1), 88-99.

Mohamed, Hamdi S (1999). Resistance strategies: Somali women's struggles to reconstruct their lives in Canada. Canadian Woman Studies Vol 19 (3), pp. 52-57. 
Mohamed, H. S. (2007). Somali single mothers in Ottawa: Challenges and opportunities of resettlement and implications for health and well-being (dissertation). Pp.1-100.

National Council of Welfare (2012). Snapshot of Racialized poverty in Canada. Retrieved from: Statistics Canada 2006 Report on Ontario Ethno-racial groups.

National Film Board of Canada (2005). Sharia in Canada: Something to fear? Retrieved in 2019 from: http://www.nfb.ca

Picot Garnett, Zhang Yan, and Hou Feng (2019) Labour Market Outcomes Among Refugees to Canada. Retrieved from Statistics Canada: https://www150.statcan.gc.ca/n1/pub/11f0019m/11f0019m2019007-eng.htm

Premji et al (2014). Precarious Work of Racialized immigrant women in Toronto: A community Based study. Access Alliance Multicultural Health.

Premji \& Shakya (2017). Pathways between under/unemployment and health among racialized immigrant women in Toronto. Ethnicity and Health. Vol. 22, No. 1, 17-35.

Preston V. \& Murnaghan (2005). Immigrants and Racialization in Canada. Canadian Issues, spring 2005. P.67.

Reitz JG (2001). Immigrant skill utilization in the Canadian labour market: Implications of human capital research. Journal of International Migration and Integration 2(3): 347378.

Ruby, T. F. (2016). Discourses of sharia law and Muslim women: A critical reflection on sharia in Canada. Feminist Formations, 28(3), 121.

Saloojee A. (2005) Social Inclusion, Anti-Racism and Democratic Citizenship. Scholars Portal: Downloaded. Laidlaw Foundation: Working Papers Series. 
Said, Edward (1979). Orientalism. Pantheon Books: New York.

Shan, Hongxia (2009). "Shaping the Re-Training and Re-Education Experiences of Immigrant Women: The Credential and Certificate Regime in Canada, " International Journal of Lifelong Education, 28(3): 353-369.

Spitzer, D. L. (2006). The Impact of Policy on Somali Refugee Women in Canada. Refuge, 23(2), pp.47-54.

Spitzer, D.L. (2007). Immigrant and Refugee Women: Recreating Meaning in Transnational Context. Anthropology in Action. Vol 14, 1 \& 2: 52-62.

Spierings N, Smits J and Verloo M (2010) Micro- and macrolevel determinants of women's employment in six Arab countries. Journal of Marriage and Family 72(5): 1391-1407.

Streeting, W. (2019, May 15) Yes, Islamophobia is a type of racism. Here's why. The Guardian. Retrieved from: https://www.theguardian.com

Tariq and Seyed (2018). An intersectional perspective on Muslim women's issues and experiences in employment. Gender Work Organ 25, Pp.495-513.

Warfa Nasir, Curtis Sarah, Watters Charles, Carswell Ken, Ingleby David and Bhui Kamaldeep (2012). Migration Experiences, Employment Status and Psychological Distress among Somali Immigrants: A Mixed Methods International study. BMC Public Health. Vol. 12, Issue 749, pp. 1-12.

Zine, Jasmin (2006). Unveiled Sentiments: Gendered Islamophobia and Experiences of Veiling among Muslim Girls in a Canadian Islamic School. Equity and Excellence in Education. Vol. 39, Issue 3, pp.239-252. 